\title{
"MÄ OPIN SITÄ KADULLA KAVEREITTEN KANSSA" - SUOMEN KIELEN KÄYTTÖÖN JA OPPIMISEEN LIITTYVIÄ KATEGORISOINTEJA MAAHANMUUTTAJA- NUORTEN HAASTATTELUPUHEESSA
}

\author{
Niina Lilja, Tampereen yliopisto
}

\begin{abstract}
Tarkastelen tässä artikkelissa haastatteluaineistoon pohjaten maahanmuuttajanuorten käsityksiä eli ajatuksia ja ideoita suomen kielen käyttämisestä ja oppimisesta. Kysyn, millaisia käsityksiä nuorilla on suomen kielestä, suomen kielen käytön ja oppimisen paikoista sekä kielen oppimisen prosessista. Analysoin aineistoani jäsenkategoria-analyysia soveltaen ja erittelen niitä ihmisiin ja paikkoihin liittyviä kategorioita, jotka jäsentävät maahanmuuttajanuorten haastattelupuhetta suomen kielestä ja kielen oppimisesta. Osoitan, että haastateltavien puheessa olennaiseksi nousee kaverin kategoria ja ensisijaisesti suomalaiset kaverit nähdään tärkeiksi oppimisen mahdollistajiksi. Kaverin kategoria nousee joissakin haastatteluissa keskeiseksi myös poissaolon kautta, ja suomalaisten kavereiden puuttuminen yhdistetään suoraan kielenkäyttötilanteiden vähyyteen. Paikkoihin liittyvistä kategorisoinneista tärkeäksi nousee vastakkainasettelu koulun ja sitä ympäröivän kieliyhteisön välillä. Näytän analyysissani, miten tämän vastakkainasettelun avulla jäsennetään suomen kielen käytön ja oppimisen paikkoja ja rakennetaan käsityksiä eri kielimuotojen arvostuksiin liittyen.
\end{abstract}

Avainsanat: jäsenkategoria-analyysi, kielen oppiminen, käsitykset, maahanmuuttajat, myöhään tulleet nuoret, suomi toisena kielenä

\section{ALUKSI}

Tarkastelen tässä artikkelissa maahanmuuttajanuorten käsityksiä suomen kielen käyttämisestä ja oppimisesta. Pohjaan analyysini haastatteluaineistoon ja kysyn, millaisia käsityksiä nuorilla on suomen kielestä, suomen kielen

Kirjoittajan yhteystiedot:

Niina Lilja

Tampereen yliopisto

niina.lilja@tuni.fi käytön ja oppimisen paikoista sekä kielen oppimisen prosessista. Analysoin aineistoani sisällönanalyyttisesti ja jäsenkategoria-analyysia soveltaen eritellen niitä ihmisiin ja paikkoihin liittyviä kategorioita, jotka jäsentävät maahanmuuttajanuorten haastattelupuhetta suomen kielestä ja kielen oppimisesta. Artikkelini tavoitteena on lisätä tietoa siitä, mitä maahanmuuttajanuoret ajattelevat suomen kielen käytöstä ja oppimisesta sekä tuoda uusia metodologisia näkökulmia käsitysten tutkimukseen.

Suomea toisena kielenään käyttäviä puhu- 
jia on koko ajan enemmän. Yhä enemmän on myös sellaisia nuoria maahanmuuttajia, jotka ovat muuttaneet Suomeen alaikäisinä turvapaikanhakijoina (noin 14-17-vuotiaina). Näistä nuorista käytetään myös nimitystä "myöhään saapuneet nuoret", koska Suomen koulujärjestelmän näkökulmasta he ovat muuttaneet Suomeen lähellä oppivelvollisuuden päättymisikää (ks. esim. Huttunen, 2013). Koska he kuitenkin ovat nuoria, heidät usein ohjataan peruskouluun, jotta he saavuttaisivat jatko-opintokelpoisuuden ja voisivat kouluttautua Suomessa ammattiin. Heidän koulutuspolkunsa Suomessa on kuitenkin tunnistettu helposti haavoittuvaksi esimerkiksi siitä syystä, että koulussa tarvittavan akateemisen kielitaidon oppiminen vie aikaa useita vuosia ${ }^{1}$ (ks. Valtion kotouttamisohjelma vuosille 2012-2015 sekä vuosille 2016-2019).

Tämän artikkelin aineistona olevissa haastatteluissa äänessä ovat nimenomaan "myöhään tulleet" nuoret, jotka haastatteluissa kertovat ajatuksiaan suomen kielen käytöstä ja oppimisesta. Analyysini havainnollistaa, että vaikka näiden nuorten koulutuspolkua on pidetty haasteellisena nimenomaan akateemisen kielitaidon hankkimisen näkökulmasta, myös - ja ehkä ennen kaikkea - arkipäiväisen kielitaidon ja itselle relevanttien suomenkielisten kieliyhteisöjen löytäminen on usealle yhtä haasteellista. Haastateltavien puheessa olennaiseksi nousee kaverin kategoria ja ensisijaisesti suomalaiset kaverit nähdään tärkeiksi oppimisen mahdollistajiksi. Kaverin kategoria nousee joissakin haastatteluissa keskeiseksi myös poissaolon kautta, ja suomalaisten kavereiden puuttuminen yhdistetään

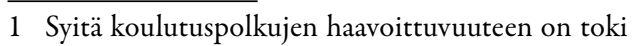
muitakin. Erityisesti asiaan vaikuttaa se, että näistä nuorista moni on tullut Suomeen yksin, ilman perhettään, millä on todennäköisesti monia vaikutuksia myös oppimisen prosesseihin. Tämä on kuitenkin kompleksinen kysymys, jonka tarkastelu jää tämän artikkelin kysymyksenasettelujen ulkopuolelle. suoraan kielenkäyttötilanteiden vähyyteen. Paikkoihin liittyvistä kategorisoinneista tärkeäksi nousee vastakkainasettelu koulun ja sitä ympäröivän kieliyhteisön välillä. Näytän analyysissani, miten tämän vastakkainasettelun avulla jäsennetään suomen kielen käytön ja oppimisen paikkoja ja rakennetaan käsityksiä eri kielimuotojen arvostuksiin liittyen.

\section{KIELENOPPIJOIDEN KÄSITYKSET TUTKIMUKSEN KOHTEENA}

Kielenoppijoiden ja -opettajien käsityksiä oppimisen kohteena olevasta kielestä ja itse oppimisen prosessista on tutkittu melko laajasti erilaisista teoreettis-metodologisista näkökulmista käsin (ks. esim. Barcelos, 2003; Kalaja, Barcelos \& Aro, 2018). Kalaja ym. (2018) summaavat, että käsitysten tutkimuksessa fokus oli alkuaikoina sen analysoinnissa, mitä oppijat ajattelivat kielen oppimisesta ja opettamisesta. Analyysin kohteena oli siis käsitysten sisältö. Myöhemmin fokus on siirtynyt sen tarkasteluun, miten käsitykset kehittyvät ja varioivat konteksteissaan. Käsityksiä ei enää tutkita niinkään yksilön ominaisuuksina, vaan niitä pidetään sosiaalisesti jaettuina ja tilanteisina (Kalaja ym., 2018).

Käsitysten tutkimisen mielekkyyttä ja tärkeyttä perustellaan usein sillä, että käsitykset ovat yhteydessä kielenkäyttäjän toimintaan erilaisissa vuorovaikutustilanteissa. Kaiken erityisesti kielen oppimiseen liittyvän toiminnan voi ajatella perustuvan kielenkäyttäjän käsitykseen siitä, mitä kieli on ja miten sitä opitaan. Käsitys kielestä ja oppimisesta voi myös ohjata oppijan havaintoja ja sitä, mitä ympäristönsä aineksia hän käyttää oppimisessaan resurssina. Esimerkiksi Alanen (2003) on sosiokulttuuriseen näkökulmaan perustuvassa tutkimuksessaan ehdottanut, että oppijoiden käsitysten voidaan ajatella toimivan eräänlaisina kielenoppimisen työkaluina, 
joilla oppijat rakentavat ja suuntaavat oppimisensa prosesseja (ks. myös Dufva, 2014; Partanen, 2013a, 2013b; van Lier, 2000). Viimeaikaisessa tutkimuksessa onkin korostettu käsityksistä tiedostumisen tärkeyttä (Kalaja ym., 2018).

Suomessa käsityksiä on tarkasteltu erityisesti sosiokulttuurisesta ja dialogisesta näkökulmasta, Bahtinin ja Vygotskin näkökulmiin pohjautuen (ks. esim. Aro, 2009; Partanen 2013a, 2013b; Suni, 2010). Tarkastelun kohteena ovat olleet tulevien kieltenopettajien käsitykset (ks. esim. Alanen, Kalaja \& Dufva, 2013) tai eri-ikäisten englanninkielen oppijoiden käsitykset kielen oppimisesta (Alanen, 2003; Aro, 2009 2016; Nikula \& Pitkänen-Huhta, 2008). Esimerkiksi Aro (2009) on eritellyt suomalaisten alakouluikäisten lasten käsityksiä englannin kielestä ja sen oppimisesta. Hänen analyysinsa näyttää, että lasten ajatuksissa kieltä opitaan ensisijaisesti oppikirjoista ja sitä varten, että olisi mahdollista keskustella ulkomaalaisten kanssa - joskus tulevaisuudessa (ks. myös Nikula \& Pitkänen-Huhta, 2008).

Suomea toisena kielenä oppivien käsityksiä analysoivat tutkimukset ovat keskittyneet aikuisiin kielenoppijoihin. Partanen (2013a) on eritellyt englanninkielisiin koulutusohjelmiin osallistuvien kansainvälisten opiskelijoiden käsityksiä suomen kielestä ja sen oppimisesta ja Partanen (2013b) puhdistuspalvelualalla toimivien maahanmuuttajien näkökulmia siihen, millaisia kielenoppimisen mahdollisuuksia ja tilanteita työyhteisön vuorovaikutuksessa syntyy. Suni (2010) on analysoinut työperusteisesti Suomeen muuttaneiden aikuisten näkökulmia työpaikan vuorovaikutustilanteissa saamaansa kielelliseen tukeen sekä siihen, miten he näkevät ammatillisen kielitaitonsa kehittyvän osana työelämän vuorovaikutustilanteita. Eritaustaisten maahanmuuttajien käsityksiä kielen käytöstä ja oppimisesta erityisesti työelämän tai järjestötoiminnan erilaisissa vuorovaikutustilanteissa on analysoitu myös useissa pro gradu -töissä (esim. Heimala-Kääriäinen, 2015; Härkönen, 2011; Mähönen, 2014; Partanen, 2012; Tourunen, 2016). Nämä tutkimukset perustuvat haastatteluaineistoihin (joko kokonaan tai osittain) ja kaikissa yhteisenä havaintona on se, että suomea toisena kielenä käyttävät oppijat kokevat oppivansa erilaisissa vuorovaikutustilanteissa osaavampien kielenkäyttäjien tuella. Aina tätä tukea ei kuitenkaan ole tarjolla, ja näissä tilanteissa kielitaidon puute koetaan esteeksi, joka vaikeuttaa esimerkiksi työyhteisön sosiaalisiin tilanteisiin osallistumista. Suomen kielen taito tunnistetaankin tärkeäksi erityisesti työelämään integroitumisen näkökulmasta (ks. myös Kokkonen 2007, Tarnanen, Rynkänen \& Pöyhönen, 2015).

Tässä artikkelissa pyrin täydentämään erityisesti suomenoppijoiden käsityksiä tarkastellutta aikaisempaa tutkimusta selvittämällä, millaisia käsityksiä suomen kielestä ja suomen kielen oppimisesta myöhään tulleilla nuorilla on, sekä pohtimalla, miten nämä käsitykset mahdollisesti ovat yhteydessä heidän kielenoppimisen prosessiinsa. Tavoitteenani on myös tuoda uusia näkökulmia käsitysten tutkimisen metodologiaan yhdistämällä aineistolähtöiseen sisällönanalyysiin jäsenkategoria-analyysia eli sen erittelyä, millaisia kategorioita haastatellut nuoret nostavat esiin käsityksistä puhuessaan, sekä tarkastelemalla, millaiset paikkakategoriat jäsentävät heidän puhettaan suomen kielen käytön ja oppimisen konteksteista.

\section{AINEISTO JA ANALYYSIMENETELMÄ}

Aineistoni koostuu 20 teemahaastattelusta. Olen tehnyt haastattelut osana etnografista tutkimusprojektia, jossa seurasin aikuisten perusopetuksessa opiskelevia maahanmuut- 
tajanuoria kahden vuoden ajan heidän suorittaessaan suomalaisen peruskoulun yläluokkia. Nämä nuoret ovat saapuneet Suomeen turvapaikanhakijoina peruskoulun päättövaiheessa eli noin 14-17-vuotiaina. Heiltä on jäänyt peruskoulu kesken kotimaassaan, ja he suorittavat Suomessa peruskoulun yläluokat saadakseen peruskoulun päättötodistuksen ja jatko-opintokelpoisuuden. Ennen peruskoulun yläluokkien aloittamista nämä nuoret ovat opiskelleet tyypillisesti noin kolmen vuoden ajan erilaisilla suomen kielen kursseilla, valmistavilla luokilla tai perusopetukseen valmistavassa opetuksessa. Haastatteluhetkellä nuoret olivat iältään kahdenkymmenen vuoden tietämillä².

Tutkimusprojektiani näiden nuorten parissa motivoi halu selvittää, miten he kehittyvät suomen kielen käyttäjinä peruskoulua suorittaessaan ja miten suomen kielen oppiminen tapahtuu osana eri kouluaineiden luokkahuonevuorovaikutusta ja arjen vuorovaikutustilanteita. Projektin aikana olin säännöllisesti läsnä eri oppiaineiden tunneilla ja videonauhoitin luokkahuoneen vuorovaikutusta. Lisäksi haastattelin kutakin nuorta projektin aikana vähintään kerran. Teemahaastatteluissa tavoitteenani oli saada tietoa siitä, mitä nuoret ajattelevat suomen kielestä ja suomen kielen oppimisesta. Haastatteluissa puhuimme siitä, 1) millainen on haastateltavan koulutausta omassa kotimaassa ja Suomessa 2) mitä kieliä hän käyttää arkipäivässään ja millaisissa kielenkäyttökonteksteissa suomen kieli on käytössä (millaisissa puhetilanteissa, millaisissa lukemisen, kirjoittamisen tai kuuntelemisen yhteyksissä) 3) missä hän ajattelee oppivansa suomen kieltä ja miten 4) mitä hän ajattelee koulussa käytetystä kielestä ja eri oppiaineiden kielistä ja 5) millaisena hän näkee tulevaisuutensa suomen kielen käyttä-

2 Aineistossa on mukana myös kaksi vanhempaa, noin 30-40-vuotiasta opiskelijaa. jänä. Haastattelujen kesto vaihtelee kahdestakymmenestä minuutista yli kahteen tuntiin. Ne on litteroitu keskustelunanalyyttisia litterointikonventioita soveltaen siten, että litteraatti on melko karkea eikä esimerkiksi puheen prosodisiin piirteisiin ole kiinnitetty kovin tarkasti huomiota (ks. liite 1). Haastattelujen litteraateissa kaikki haastateltavien nimet ovat pseudonyymejä. Joissakin kohdin olen muuttanut myös paikkojen nimiä ja tarvittaessa poistanut viittauksia haastateltavien äidinkieleen heidän anonymiteettinsä turvaamiseksi.

Aineiston analyysi on ollut kaksivaiheinen. Ensin identifioin haastatteluaineistosta ne kohdat, joissa puhutaan suomen kielen käyttämisestä ja oppimisesta. Jo näiden kohtien tunnistaminen ja kokoaminen aineistosta johti yhteen tärkeään havaintoon. Kielen käytöstä ja oppimisesta puhutaan haastatteluista usein yhtenä ja samana asiana eikä niiden välille tehdä suurta eroa: haastateltavien mukaan kieltä oppii sitä käyttämällä.

Tämä ensimmäinen vaihe aineiston analyysia noudatteli siis aineistolähtöisen sisällönanalyysin periaatteita (Tuomi \& Sarajärvi, 2002). Kun olin tunnistanut aineistosta suomen kielen käyttöön ja oppimiseen liittyvät katkelmat, lähdin analysoimaan haastattelupuhetta tarkemmin jäsenkategoria-analyysia soveltaen (ks. esim. Baker, 1997, 2002; Nikander, 2010, 2012). Jäsenkategoria-analyysi on aineistovetoinen analyysimenetelmä, ja tavoitteena on päästä käsiksi siihen, miten aineiston osallistujat itse kuvaavat ja kategorisoivat aineistossa keskeisiä teemoja. Kategorisointeja tutkitaan monilla eri tieteenaloilla ja eri lähtökohdista käsin. Tässä käyttämäni jäsenkategoria-analyysi pohjaa etnometodologiseen ajatteluun (ks. Hester \& Eglin, 1997; Jokinen, Juhila \& Suoninen, 2012; Nikander, 2010). Kiinnostukseni kohdistuu siis siihen, miten haastattelupuheessa luokitellaan ja nimetään kielen oppimiseen liittyviä ihmisiä ja 
paikkoja ja näin rakennetaan niihin liittyviä kategorioita.

Olennainen analyysiani ohjaava lähtökohta on se, että tutkin haastatteluja vuorovaikutustilanteina. Haastatteluvuorovaikutuksessa rakentuvien kategorisointien näkökulmasta molempien vuorovaikutustilanteen osallistujien (haastattelijan ja haastateltavan) toiminnalla on olennainen merkitys siinä, millaiset kategorisoinnit nousevat merkityksellisiksi. Haastattelutilanne ei ole luonnollinen vuorovaikutustilanne sikäli, että se on tutkijan järjestämä ja haastateltava on yleensä kutsuttu puhumaan tietyn kategorian edustajana (ks. Speer, 2002). Tässä tutkimuksessa haastattelen maahanmuuttajanuoria nimenomaan suomen kielen oppijoina ja he tietävät, että haastattelijana olen tutkija, joka on kiinnostunut heidän oppimisprosesseistaan erityisesti suomen kielen näkökulmasta. Nämä tutkijan ja suomen kielen oppijan kategoriat myös verbalisoidaan jokaisen haastattelun aluksi. Siksi on selvää, että nämä kategoriat jollakin tavalla jäsentävät vuorovaikutustilannetta ja sitä, millaiset seikat siinä nousevat olennaisiksi, vaikka näihin kategorioihin ei suoraan puheella suuntauduttaisikaan muutoin kuin haastattelutilanteen aluksi. Analysoin haastatteluaineistoja näytteinä vuorovaikutuksesta, jossa rakennetaan suomen kielen käyttöön ja oppimiseen liittyviä kategorisointeja, jotka ovat myös seurauksellisia sikäli, että niistä puhuminen samalla rakentaa sitä kielellistä ja sosiaalista todellisuutta, jossa haastatteluvuorovaikutukseen osallistuvat elävät ja jonka mukaisesti he toimivat (ks. Alasuutari, 1995; Nikander, 2012).

Etnometodologisessa jäsenkategoria-analyysissa on alun perin kiinnitetty huomiota ensisijaisesti ihmisiä kuvaaviin kategoriatermeihin. Tässä tarkastelun kohteena olevassa haastatteluaineistossa keskeisiä ihmistä kuvaavia kategoriatermejä ovat esimerkiksi kaveri, suomalainen ja opettaja. Näiden ka- tegoriatermien lisäksi analysoijan huomio kiinnittyy myös kategoriasidonnaiseen toimintaan. Arkijärkeilyssämme liitämme tiettyihin kategorioihin tietynlaista toimintaa: esimerkiksi opettajalle ominainen kategoriasidonnainen toiminta on opettaminen. Kategorioista puhuttaessa kategoriatermiä ei tarvitsekaan aina eksplisiittisesti mainita vaan myös kategoriasidonnaisesta toiminnasta puhuminen tekee kategorian vuorovaikutuksellisesti läsnä olevaksi. (Schegloff, 2007a, 2007b.) Ihmisiin liittyvien kategorisointien lisäksi myös paikkoihin, ympäristöihin tai vaikkapa esineisiin liittyvät kategorisoinnit voivat olla analyysissa keskeisiä. Tässä analysoitavassa haastatteluaineistossa olennaisia paikkoihin liittyviä kategorioita ovat koulu ja sen vastakohdaksi rakentuvat paikkakategoriat (katu, ulkopuoli), jotka olennaisesti jäsentävät sitä todellisuutta, jota haastatteluvuorovaikutuksessa kuvataan suhteessa kielen käyttöön ja oppimiseen.

\section{KAVERIT, OPETTAJAT, KOULU JA KATU: KIELEN OPPIMISTA JÄSENTÄVÄT KATEGORIAT}

\subsection{Suomalaisen kaverin merkityksellinen kategoria}

Kaveri on keskeinen haastatteluaineistossa esiin nouseva kategoria, joka jäsentää puhetta suomen kielen käytöstä ja oppimisesta. Kaverit nousevat aineistossa esiin poikkeuksetta suomen kielen käytöstä ja oppimisesta puhuttaessa. Toisaalta haastateltavat kertovat siitä, että he käyttävät suomea kavereiden kanssa ja siinä samalla oppivat kieltä. Toisaalta kaverin kategoria nousee esiin myös poissaolon kautta: kaikilla suomalaisia kavereita ei ole ja siksi myös suomen kielen puhumisen mahdollisuudet ovat vähäiset. Lisäksi kaverin kategoria jäsentää jossain määrin myös puhetta eri kielimuodoista, sillä haastateltavat puhuvat 
toistuvasti siitä, miten koulun ja sitä ympäröivän yhteiskunnan kielimuodot eroavat toisistaan. Vuorovaikutuksessa kavereiden kanssa puhekielen rekisterit olisivat arvokkaita. Koulu taas ei valmenna näiden rekistereiden haltuunottoon, mitä joissakin haastatteluissa kritisoidaan (ks. esimerkit 7 ja 8).

Esimerkki 1 on peräisin haastattelusta, jossa on kaksi haastateltavaa, Ahmed ja Ibrahim. Haastattelija kysyy, missä haastateltavat ovat mielestään oppineet suomea parhaiten. Haastattelijan missä-kysymys hakee vastaukseksi nimenomaan paikkaa, ja Ahmed vastaa epäröimättä - jo ennen kuin haastattelija on saanut kysymystään loppuun - että hän on oppinut suomea kadulla (r. 4).

Esimerkki 1. Suomea opitaan kavereiden kanssa kadulla

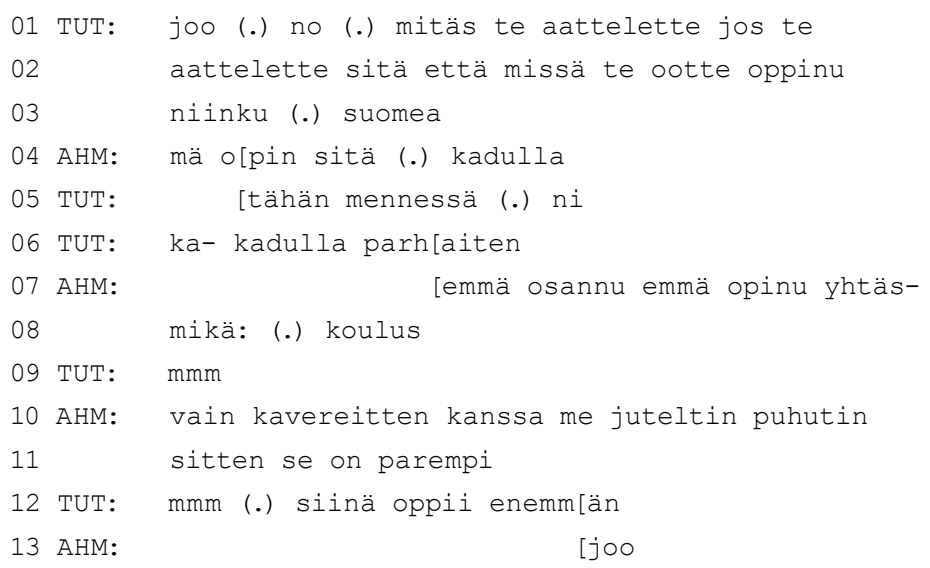

Ahmedin puheessa paikkakategoria katu saa vastinparikseen koulun ja nämä kaksi jäsentyvät vastakohdiksi toisilleen: katu asettuu siis koulun vastakohdaksi merkitsemään koulun ulkopuolista maailmaa. Koulussa Ahmed ei koe oppineensa vaan oppiminen tapahtuu hänen mukaansa nimenomaan koulun ulkopuolissa kielenkäyttöympäristöissä kaverien kanssa juttelemalla (r. 10-11). Huomionarvoista on myös se, että Ahmed samastaa vastauksessaan kielen käytön ja oppimisen: oppiminen tapahtuu puhumalla (r. 10, 11). Tällainen näkemys kaiuttaa nykytutkimuksessa keskeistä näkökulmaa, jonka mukaan oppiminen tapahtuu nimenomaan vuorovaikutuksessa eikä kielen käyttöä ja oppimista voi pitää toisistaan erillisinä kategorioina (ks. esim. Douglas Fir Group, 2016).
Samanlainen käsitys kavereiden ja koulun ulkopuolisen kielenkäyttöympäristön merkityksestä näkyy useissa muissakin haastatteluissa: lähes kaikki haastateltavat ovat yhtä mieltä siitä, että kaverit ovat tärkeä oppimisen resurssi - tai olisivat, jos heitä olisi.

Kavereiden puute yhdistetään haastatteluissa suoraan suomen kielen käytön ja oppimisen vähäisiin mahdollisuuksiin. Esimerkki 2 on ote Musan haastattelusta. Musa kertoo, että käyttää koulun ulkopuolella lähinnä äidinkieltään ja syyksi suomen kielen käytön vähyyteen hän mainitsee sen, että suomalaisia kavereita ei ole. 
Esimerkki 2. Puuttuvan suomalaisen kaverin kategoria

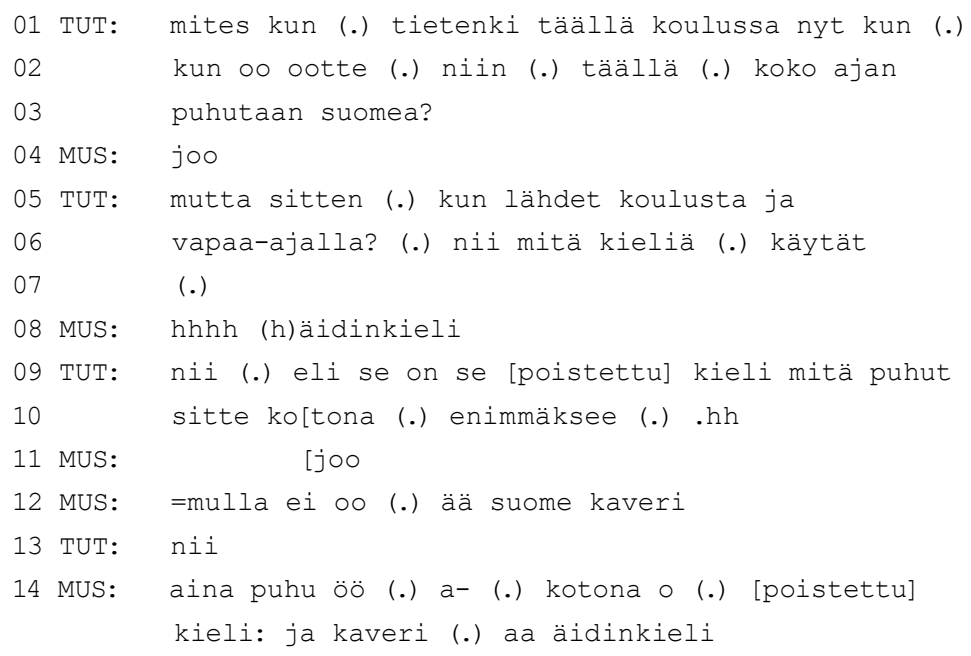

Musa vastaa käyttävänsä vapaa-ajallaan lähinnä äidinkieltään (r. 8) ja selventää tämän johtuvan siitä, että "mulla ei oo suome kaveri" (r. 12). Musan vastauksessa siis nimenomaan suomalaisten kavereiden puute asettuu selittämään sitä, miksi suomea ei käytetä vapaaajalla. Suomalaisen kategoria määrittyy tässä siis ensisijaisesti kielen kautta.

$\mathrm{Ne}$ haastateltavat, jotka haastatteluissa kertovat käyttävänsä suomea vain vähän vapaa-ajallaan, puhuvat usein suomalais- ten kavereiden puuttumisesta. He kertovat haastatteluissa myös hypoteettisia kuvauksia (ks. Georgakopoulou, 2007) siitä, että jos kavereita olisi, olisi suomen kielen käytölle ja oppimiselle myös suotuisammat mahdollisuudet. Esimerkki 3 havainnollistaa tällaista tilannetta. Siinä Ali kertoo puhuvansa vain vähän suomea vapaa-ajallaan, koska suomalaisia kavereita ei ole (r. 4, 6). Hän kuitenkin pohtii, että jos kavereita olisi, myös oppimisen mahdollisuudet olivat paremmat (r. 16-18).

Esimerkki 3. Puuttuvat suomalaiset kaverit

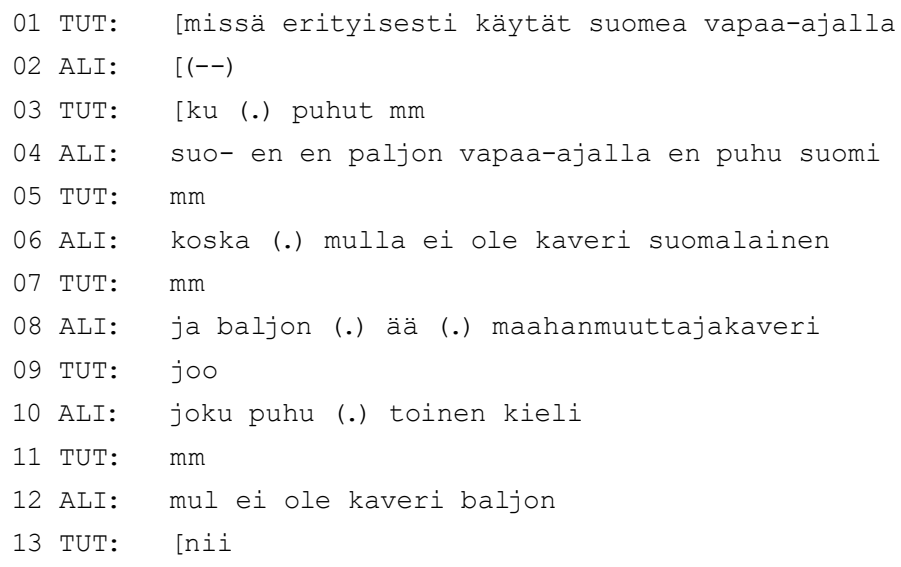




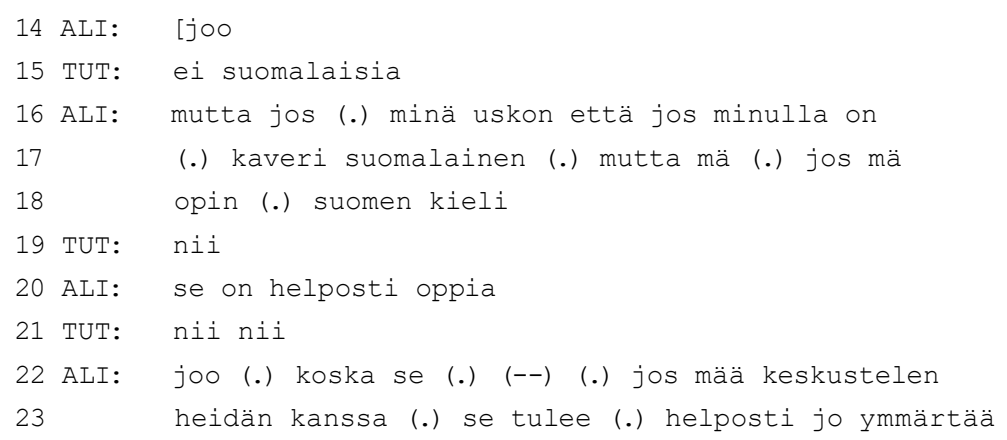

Myös Ali lisää sanaan kaveri täsmentävän määreen suomalainen. Suomalaisen kaverin vastakohtapariksi hänen puheessaan asettuu maahanmuuttajakaveri, joita hänellä on paljon (r. 8). Hän märrittelee nämä kaksi kaverikategoriaa nimenomaan kielen kautta: suomalaisia ovat ne, joiden kanssa olisi mahdollista puhua suomea, ja maahanmuuttajia ovat ne, jotka puhuvat toista kieltä (r. 10). Suomalaista kaveria määrittää hänen puheessaan myös poissaolo, sillä hänellä ei ole paljon suomalaisia kavereita. Tähän liittyen kiinnostava on Alin pieni kertomus siitä, että jos hänellä olisi kavereita, hän myös oppisi (r. 16-23). Tämä kertomus oletetuista oppimisen mahdollisuuksista vahvistaa sitä muissakin haastatteluissa esille tulevaa käsitystä, että nimenomaan suomea puhuvat kaverit olisivat tärkeä kielen oppimisen resurssi.
Myös esimerkki 4 havainnollistaa tätä. Esimerkki on ote Karifin pidemmästä kerronnasta, jossa hän on kertonut samasta kotimaasta lähtöisin olevasta ystävästään, joka on oppinut suomea hyvin siksi, että hän asui Suomessa monta vuotta ilman samaa kieltä puhuvia maahanmuuttajakavereita ja käytti paljon suomen kieltä suomalaisten kavereidensa kanssa. Karif ei siis tässä puhu omista kokemuksistaan, vaan on jo aikaisemmin kertonut puhuvansa suomea vapaa-ajallaan vain vähän siksi, että suomalaisia kavereita ei juurikaan ole. Hänen kerrontansa kuitenkin osoittaa, että myös hän on tunnistanut kavereiden olevan olennaisen oppimisen resurssi. Esimerkin alussa Karif jatkaa kertomustaan eritellen, miksi kavereiden kanssa puhuessa oppii hyvin kieltä.

Esimerkki 4. Jos kavereita olisi, oppisi

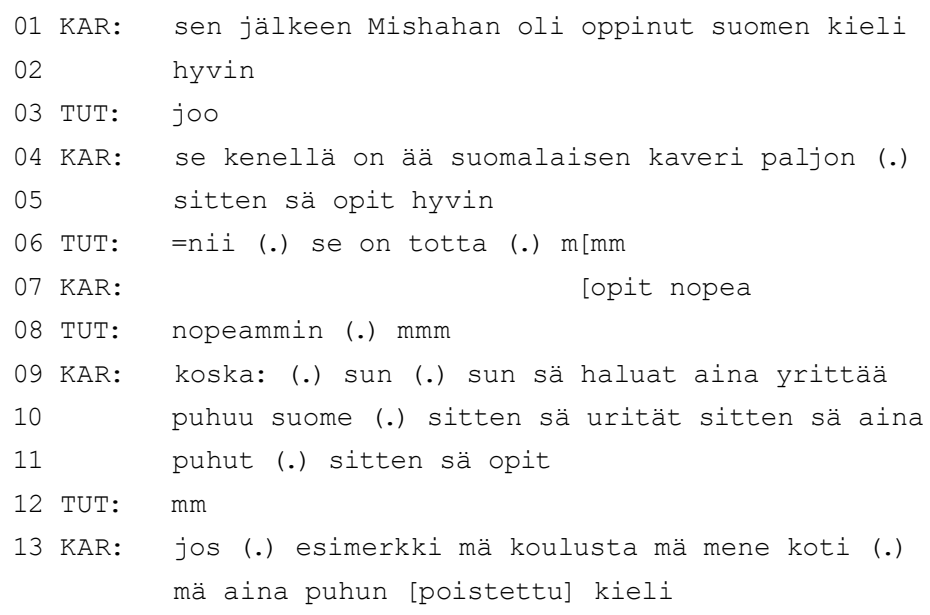


Karifin vastauksesta välittyy käsitys, jonka mukaan nimenomaan suomalaiset kaverit synnyttävät motivaation käyttää kieltä ja kieltä käyttämällä syntyy mahdollisuuksia oppia (r. 9-11). Kaverit määrittyvät tässä siis oppimismotivaation aikaansaajiksi, ja samoin kuin edellisissä esimerkeissä myös Karifin puheessa on läsnä ajatus siitä, että nimenomaan puhumalla oppii. Olennaista on kuitenkin se, että myös Karifin kuvaus on hypoteettinen, samoin kuin Alin esimerkissä 2 kuvailema tilanne. He siis ovat tunnistaneet sen, että kavereiden kanssa puhumalla olisi mahdollista oppia. Heitä itseään tämä tilanne ei kuitenkaan kosketa, koska suomalaisia kavereita ei ole. Karif lopettaakin kertomuksensa viitauksella omaan tilanteeseensa, joka on se, että koulun jälkeen kotiin mentyään hän puhuu omaa äidinkieltään samankielisten kavereiden kanssa.

Yllä esitetyissä esimerkeissä haastateltavat siis kertovat kuin yhdestä suusta kavereiden merkityksestä. Kaverit antavat syyn käyttää suomen kieltä - tai antaisivat, jos heitä oli- si. Kavereiden kanssa juttelemalla voi myös oppia kieltä. Useissa yllä olevissa esimerkeissä korostuu nimenomaan kavereiden puute, mutta tämä ei koske kaikki haastateltavia vaan joillakin heistä on paljonkin suomalaisia kavereita. Ne haastateltavat, jotka raportoivat käyttävänsä suomea myös vapaa-ajallaan, erittelivät haastatteluissaan melko analyyttisesti sitä, miten kielen oppiminen vuorovaikutuksessa kaverin kanssa tapahtuu. Karif toi yllä olevassa esimerkissä 4 esille sen, että kaverit tuovat kielen oppimiseen motivaatiota. Tämän lisäksi haastatteluaineistossa puhutaan esimerkiksi siitä, että kavereilta on mahdollista kysyä tarkennuksia tilanteessa, jossa kohdataan ymmärtämisen ongelmakohtia, tai apua siihen, miten jokin asia ilmaistaan.

Esimerkki 5 on suoraa jatkoa esimerkille yksi, jossa Ahmed on kertonut oppivansa suomea parhaiten kadulla jutellessaan kavereiden kanssa. Tähän jatkoksi haastattelija kysyy tarkennusta siihen, miten oppiminen näissä keskustelutilanteissa tapahtuu (r. 14)

Esimerkki 5. Kavereilta voi kysyä merkityksiä

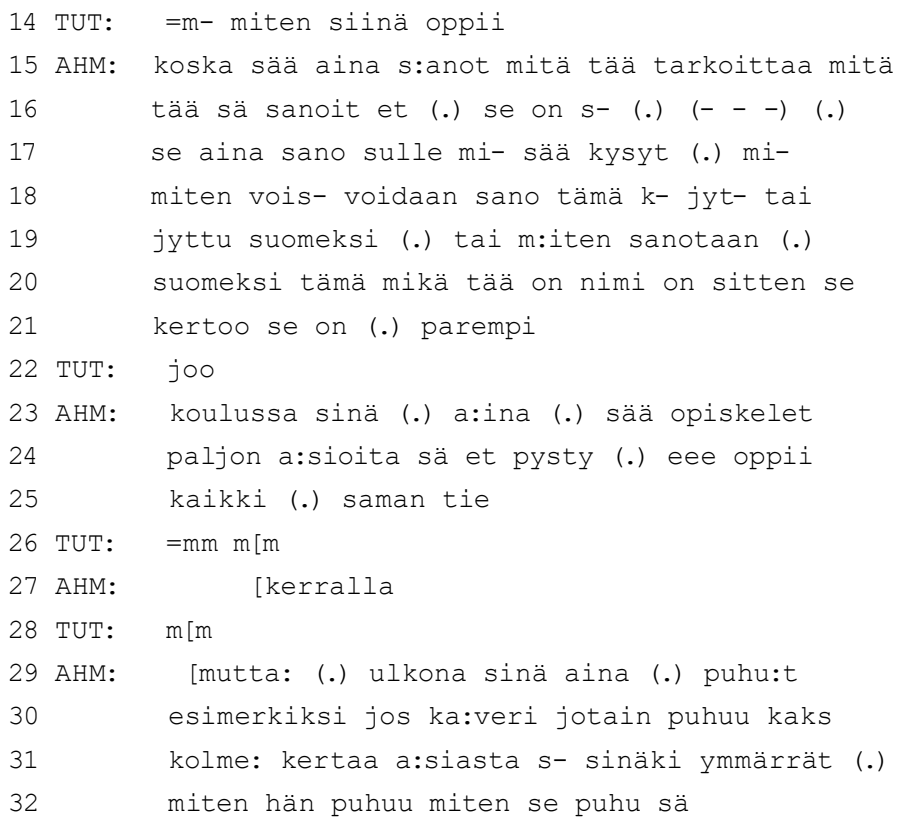


Ahmedin puheessa rakentuu jälleen vastakkainasettelu koulun ja sitä ympäröivän kielimaailman välille. Koulun ulkopuoliseen kieliympäristöön Ahmed viittaa nyt kategorialla ulkona (r. 29). Oppimisympäristöt näissä vastakkain asetetuissa paikoissa ovat Ahmedin kertomuksessa erilaiset. Koulussa tulee paljon asioita ja kaikkea ei voi oppia saman tien (r. 23-25). Ulkona, vuorovaikutuksessa kaverin kanssa, taas on läsnä toiston mahdollisuus: kaveri voi puhua saman asian monta kertaa, ja ymmärtäminen mahdollistuu (r. 30-32). Samoin hänen mukaansa keskustelussa voi kysyä, mitä mikäkin ilmaus tarkoittaa tai miten jokin asia ilmaistaan suomeksi, ja tällaisissa tilanteissa suomalainen kaveri auttaa. Tämän kaverilta saadun tuen avulla sitten myös opitaan.

Ahmedin mainitseman vuorovaikutuksessa oppimisen menetelmät ovat samoja, joita on identifioitu ja analysoitu myös esimerkiksi aikaisemmassa keskustelunanalyyttisessä kakkoskielisen vuorovaikutuksen ja kielen oppimisen tutkimuksessa. On esimerkiksi ha- vaittu, että ymmärtämisen ongelmakohdissa toisen kielen puhujat voivat käyttää keskustelukumppaniaan oppimisen resurssina ja kysyä suoraan ongelmallisten sanojen merkityksestä (Lilja, 2010; Strömmer, 2017). On myös analysoitu tilanteita, joissa toisen kielen puhujat kysyvät keskustelukumppaneiltaan apua siihen, miten tietty asia ilmaistaan kohdekielellä, aivan kuten Ahmedkin kertoo (ks. esim. Svennevig, 2017). Ylipäätään keskustelukumppaneilta vuorovaikutuksessa saatavan tuen merkitys ja esimerkiksi toistamisen mahdollisuus ymmärtämisen ongelmakohtien selvittämisessä ja kielellisen prosessoinnin tukemisessa on tunnistettu vuorovaikutusanalyyttisessa tutkimuksessa (Savijärvi, 2011; Suni, 2008). Se, että haastateltavat raportoivat näistä samoista keinoista oman kielen oppimisensa menetelminä, kertoo siitä, että he tunnistavat kielen oppimisen mahdollisuudet tarkasti ja osaavat eritellä niitä analyyttisesti.

Esimerkissä 6 haastateltava Dima esittää syitä sille, miksi kaverit ovat kielenoppimisessa tärkeässä roolissa.

Esimerkki 6. Kavereilta voi kysyä turvallisesti monta kertaa

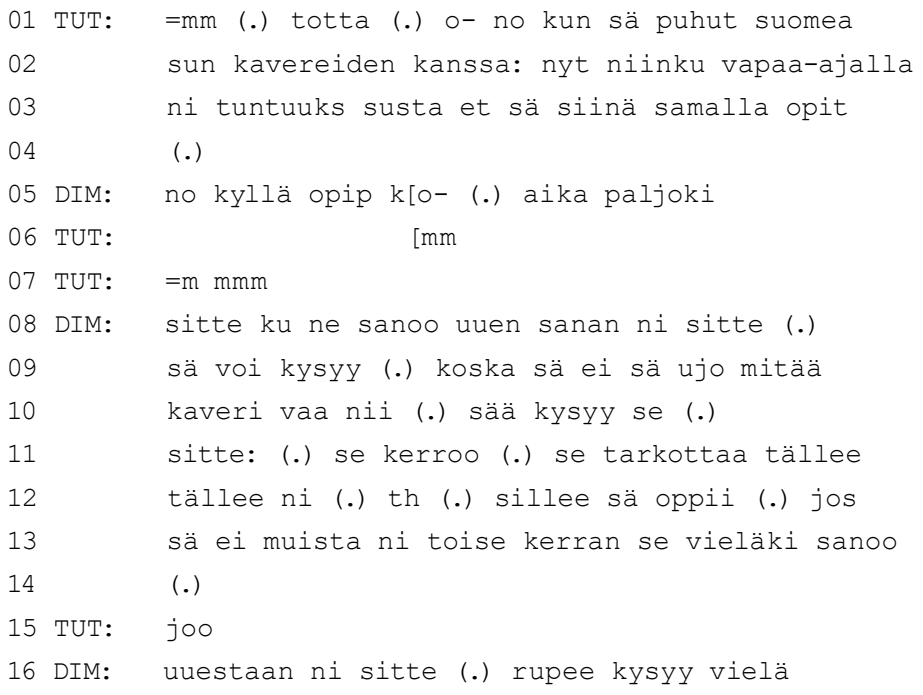


Myös Diman puheessa merkitykselliseksi oppimisen mahdollistajaksi nousee se, että vuorovaikutuksessa kaverin kanssa on mahdollista kysyä. Dima tarkentaa, että kysymisen mahdollisuus on esimerkiksi tilanteissa, joissa kaveri käyttää uutta sanaa, ja kysyminen on mahdollista, koska kaverin kanssa keskustelussa "ei sä ujo mitään" (r. 9). Tulkitsen Diman tässä tarkoittavan, että kaverin kanssa keskustellessa ei ujostuta vaan vuorovaikutustilanne on turvallinen ja tämä nimenomaan helpottaa kysymistä.

Kaikkiaan haastateltavat siis tuntuvat jakavan käsityksen siitä, että vuorovaikutuksessa suomalaisten kavereiden kanssa oppii tai olisi mahdollisuus oppia. Lisäksi he osaavat eritellä melko yksityiskohtaisesti sitä, miksi ja miten näissä vuorovaikutustilanteissa opitaan. Esiin nousee kavereiden mukanaan tuoma puhumismotivaatio, vuorovaikutussuhteen turvallisuus sekä kysymisen ja tarkentamisen mahdollisuus. Nämä kaikki ovat asioita, joita on tunnistettu myös kielen oppimisen vuorovaikutusanalyyttisessa tutkimuksessa ja joita ylipäätään voi pitää keskeisinä oppimisen keinoina monikielisessä maailmassa, jossa kielellisiä resursseja on osattava ottaa käyt- töön vuorovaikutustilanteissa luovasti, jotta pärjäisi kielellisesti vaihtelevissa ja kompleksisissa vuorovaikutustilanteissa (ks. Douglas Fir Group, 2016).

Ihmisiin liittyvistä kategorioista suomalainen kaveri nousee siis haastatteluissa kaikkein keskeisimmäksi puhetilaisuuksien ja kielen oppimisen mahdollisuuksien määrittäjäksi. Kielenkäyttöä ja oppimista jäsentävistä paikoista haastatteluissa puhutaan merkityksellisenä erityisesti koulun ja sitä ympäröivän kielimaailman vastakkaisuudesta. Siirryn seuraavaksi tarkastelemaan tätä.

\subsection{Koulun ja kadun erilaiset kielimaailmat}

Haastateltavat ovat hyvin yksimielisiä siitä, että koulussa käytetään erilaista kielimuotoa kuin koulun ulkopuolella. Näihin kielimuotoihin yhdistyy haastattelupuheessa paikoin voimakkaitakin arvolatauksia. Esimerkki 7 on Ahmedin ja Ibrahimin haastattelusta, jossa koulun ja sitä ympäröivien kielenkäyttöympäristöjen välille rakentuu hyvin jyrkkä vastakkainasettelu. Heidän käsitystensä mukaan koulussa opittavalla kielellä on arvoa lähinnä vain koulussa.

Esimerkki 7. Koulun kieli tarpeen vain koulussa

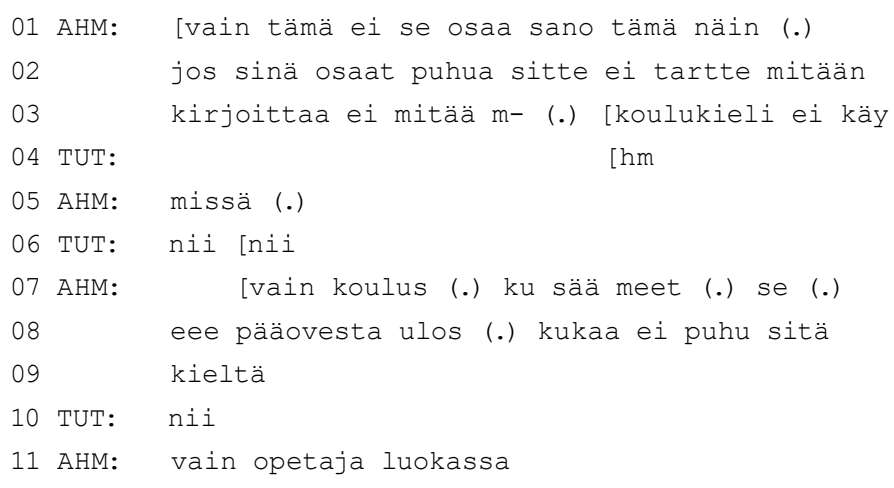


Ahmed siis raportoi, että koulussa opitun kielen käyttömahdollisuudet rajoittuvat koulun pääoveen: kun siitä astuu ulos, kukaan ei enää puhu samaa kieltä. Koulun kielen puhujaksi märittyy hänen puheessaan ennen kaikkea opettaja luokassa (r. 11). Tässä siis rakentuu hyvin selvä vastakkainasettelu kahden eri paikkakategorian välille: on koulu, jossa puhutaan koulun kieltä, ja koulun ulkopuolinen maailma, jossa koulun kielellä ei ole mitään käyttöä. Näin jyrkän vastakkainasettelun kuvaaminen ei synny tyhjästä, vaan pohjautuu todennäköisesti Ahmedin kokemuksiin kielenkäyttäjänä. Haastattelun jatko selittää tätä, sillä myöhemmin haastattelussa Ahmed tuo esiin näiden eri paikkakategorioiden ja niihin liittyvän kielenkäyttötodellisuuden seurauksellisuuden oman elämänsä näkökulmasta. Esimerkissä 8 hän kertoo, että jos koulun kieltä käyttää luokan ulkopuolella, tulee tunnistetuksi henkilöksi, joka on uusi Suomessa (r. 5).

Esimerkki 8. Kieli kategorisoinnin välineenä

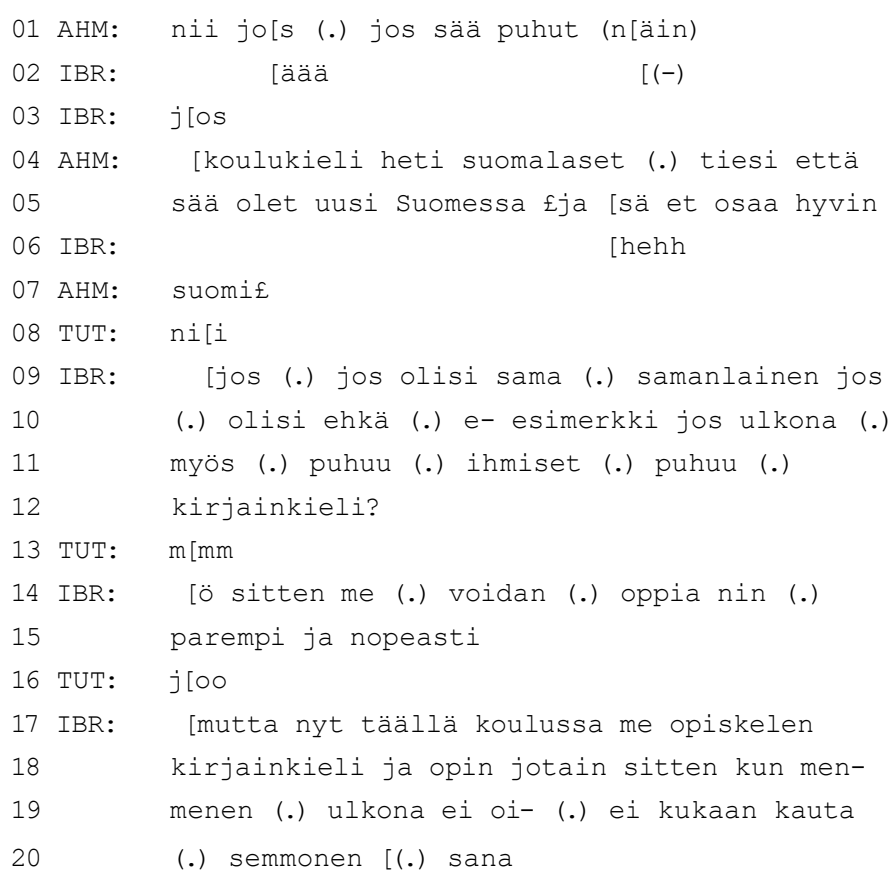

Ahmedin käyttämä "uuden suomalaisen" kategoria on kiinnostava. Hänen puheessaan tämä kategoria märitttyy sitä kautta, että uusi suomalainen puhuu "koulun kieltä", mistä vuorovaikutuskumppanit heti tietävät, että hän ei osaa kieltä hyvin. Uutta suomalaista siis luonnehtii tietynlainen kielitaidottomuus tai "ei-hyvin-osaaminen", joka liittyy nimenomaan puhekielen rekisterin hallintaan ja siihen, että uusi suomalainen puhuu koulun kieltä eli yleiskielisesti.

Lehtonen (2015) on tutkinut monikielisten nuorten kielellisiä käytänteitä eteläsuomalaisessa koulussa ja tehnyt kiinnostavan havainnon siitä, että tietyt yleiskielen piirteet, kuten esimerkiksi minä-pronominin käyttö, liitetään joissakin konteksteissa nimenomaan suomea oppivien tai "ulkomaa- 
laisten" puheeseen ja näiden piirteiden avulla voidaan esimerkiksi "esittää" huonoa suomea. Onkin kiinnostavaa, että tässä haastattelukatkelmassa Ahmed ja Ibrahim raportoivat aivan samankaltaisesta havainnosta. Heidän raportoimansa kokemus on merkittävä, sillä se on kokemus siitä, miten kieli jakaa ihmisiä eri ryhmiin. Kysymys ei ole siitä, etteivätkö Ahmed ja Ibrahim osaisi puhua suomea, vaan kyse on kielen eri rekistereiden hallinnasta ja siitä, että pystyäkseen osallistumaan täysipainoisesti sosiaalisiin vuorovaikutustilanteisiin täytyisi hallita tilanteessa käyttökelpoinen rekisteri.

Haastattelukatkelman jatko osoittaa, että Ahmedin ja Ibrahimin käsityksen mukaan koulussa opiskelu ei valmenna tämän koulun ulkopuolella merkityksellisen rekisterin hallintaan, sillä koulussa opiskellaan kirjakieltä, jota kukaan koulun ulkopuolella ei käytä (r. 17-20). Ibrahim visioi sitä mahdollisuutta, että jos koulun ja sitä ympäröivän kieliympäristön kielet olisivat samanlaiset eli jos esimerkiksi ihmiset myös koulun ulkopuolella puhuisivat kirjakieltä, kielen oppiminen olisi nopeampaa (r. 9-15). Eri kielenkäyttöympäristöjen kielimuotojen erilaisuus mieltyy siis tässä myös kielen oppimista hankaloittavaksi tekijäksi.

Koulun ja sitä ympäröivän kielimaailman erilaisuus kaiuttaa toisaalta myös Cumminsilta (1984) peräisin olevaa jakoa arkipäivän kielitaitoon ja koulussa tarvittavaan akateemiseen kielitaitoon. Cumminsin (1984) käsitteistyksessä nimenomaan akateemisen kielitaidon hankkimisen ajatellaan vievän aikaa ja vaativan panostusta. Sama ajatus on läsnä myös siinä poliittisessa keskustelussa, jossa peruskoulun päättövaiheessa Suomeen muuttaneiden eli "myöhään tulleiden" nuorten kotoutumisesta on kannettu huolta ennen kaikkea sen vuoksi, että heidän koulutuspolkujensa jatkuminen on haluttu turvata (ks. esim. Valtion kotouttamisohjelma vuosille
2012-2015, 2016-2019). On tunnistettu, että nämä nuoret ovat haasteellisessa tilanteessa esimerkiksi juuri akateemisen kielitaidon oppimisen suhteen: kouluaineiden opiskelussa tarvittavan kielitaidon hankkiminen on aikaa vievä prosessi. Monessa tutkimuksessa on kuitenkin tehty myös havaintoja siitä, että sosiaalisen jokapäiväisen kielitaidon hankkiminen on erityisesti tärkeää, jotta voisi päästä mukaan merkityksellisiin sosiaalisiin tilanteisiin joko työpaikoilla tai vapaa-ajalla (ks. esim. Härkönen, 2011; Kokkonen, 2010; Tarnanen, Rynkänen \& Pöyhönen, 2015). Tämä näkyy selvästi myös Ahmedin ja Ibrahimin kertomissa kokemuksissa, jotka liittyvät siihen, millaisia arvostuksia nämä haastateltavat eri kielimuotoihin liittävät: koulun kieli näyttäytyy heille melko hyödyttömänä, koska sillä ei ole käyttöä koulun seinien ulkopuolella eli siinä maailmassa, joka on heille merkityksellinen ja jossa toimivat myös kielen käytön ja oppimisen mahdollisuuksien kannalta merkitykselliset kaverit.

\subsection{Heikot vuorovaikutussubteet ja oppimisen mabdollisuudet}

Haastatteluvuorovaikutuksessa puhuttiin selvästi vähemmän muista kielen käytön ja oppimisen tilaisuuksista kuin keskusteluista suomalaisten kavereiden kanssa. Muutamat haastateltavat nostivat kuitenkin esiin myös esimerkiksi erilaiset asiointilanteet ja opettajien merkityksen kielen oppimisessa. Esimerkissä 9 Jarrah mainitsee ensin kaupungin keskustan ja kaupan paikkoina, joissa hän käyttää suomen kieltä vapaa-ajallaan. 
Esimerkki 9. Jarrahin kielen käytön paikat

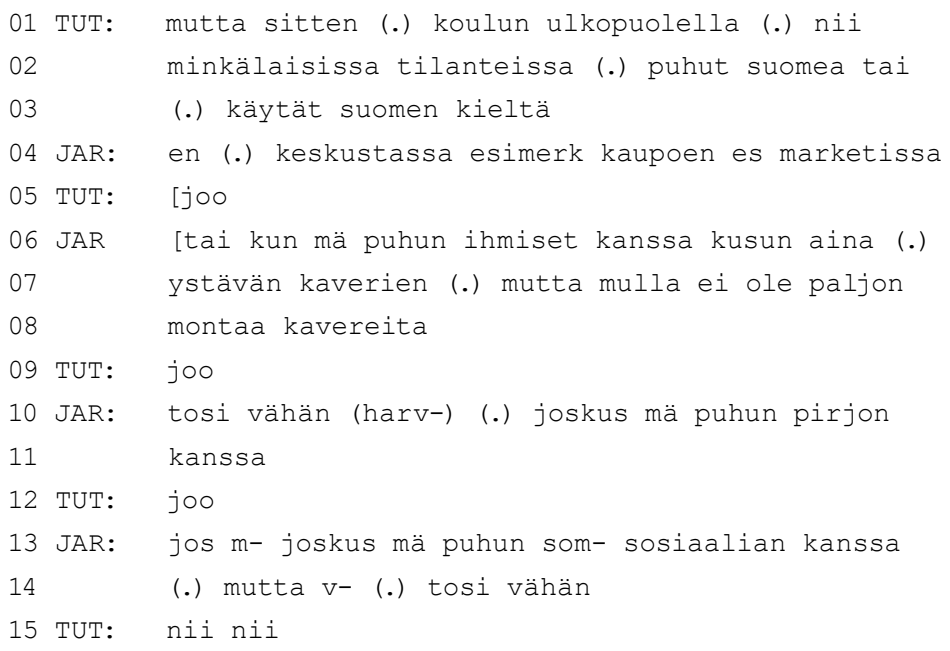

Keskustan ja kaupan mainittuaan Jarrah siirtyy kuitenkin puhumaan kavereista ja toteaa, että hänellä ei ole montaa kaveria. Myös hänen puheessaan kavereiden puuttuminen yhdistyy puhetilanteiden vähyyteen. Hänen kertomuksensa jatko vahvistaa mielikuvaa kavereiden vähyydestä, sillä hän mainitsee nimeltä Pirjon, jonka kanssa hän käyttää suomea ${ }^{3}$. Tämän jälkeen Jarrah vielä kertoo puhuvansa "sosiaalian" kanssa, minkä tulkitsen viittavan sosiaalityöntekijään. Vaikka siis myös Jarrahin kertomuksessa korostuu kavereiden merkityksellisyys, se osoittaa myös, että erilaiset asiointitilanteet tai virallisemmat keskustelut esimerkiksi sosiaalityöntekijöiden kanssa tarjoavat tärkeitä mahdollisuuksia suomen kielen käytölle luokkahuoneen ulkopuolella.

Kokkonen (2010) kirjoittaa pakolaistaustaisten maahanmuuttajien vuorovaikutussuhteita käsittelevässä väitöskirjassaan "heikoista vuorovaikutussuhteista" eli vuorovaikutussuhteista esimerkiksi juuri sosiaalityöntekijöiden, lääkäreiden tai opettajien kanssa. Hä-

3 Pirjo on myös haastattelijalle tuttu etunimen perusteella, ja siksi häneen on tässä mahdollista viitata näin. nen tuloksissaan nousee esille havainto siitä, että maahanmuuttajien kokemusmaailmassa nämä suhteet voivat olla hyvin merkityksellisiä monella tavalla. Merkityksellisiksi nämä suhteet tulevat esimerkiksi juuri sen vuoksi, että suomalaisten kavereiden ja ystävien puuttuessa nämä ammatilliset suhteet ovat ainoita suoria kontakteja kantaväestöön. Tässä haastatteluaineistossa nousee esiin se, että nämä suhteet ovat tärkeitä myös suomen kielen käytön näkökulmasta.

Esimerkissä 10 Musa vastaa kysymykseen siitä, missä hän on mielestään oppinut parhaiten suomea. Tässä Musan haastattelussa (ks. myös esimerkki 2) on käynyt jo aikaisemmin ilmi se, että hänellä ei ole suomalaisia kavereita eikä juurikaan suomen kielen käytön mahdollisuuksia vapaa-ajalla. Musa vastaakin, että hän on oppinut suomea parhaiten valmistavalla luokalla ollessaan, koska opettaja oli hyvä. 
Esimerkki 10. Opettajan merkityksellisyys

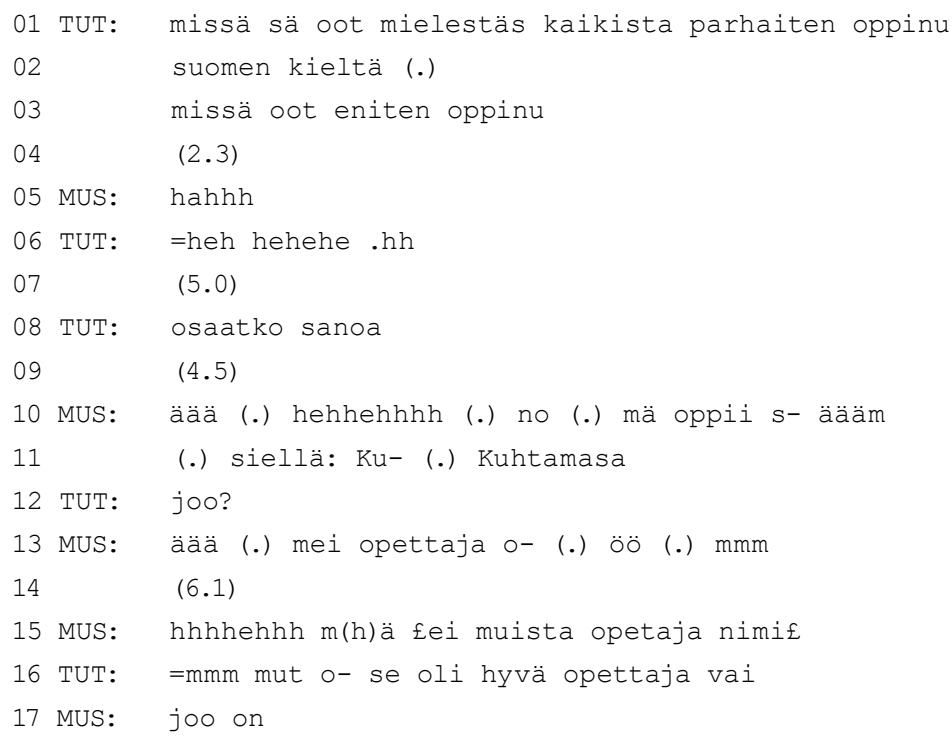

Musa mainitsee vastauksessaan ensin tietyn koulun, josta on puhuttu jo aikaisemmin haastattelussa (r. 10-11). Hän on ollut kyseisessä koulussa valmistavassa opetuksessa. Hän kuitenkin jatkaa tämän jälkeen vastaustaan viittauksella opettajaan, jonka nimeäjää sitten muistelemaan (r. 13, 15). Haastattelija tarjoaa tulkinnaksi, että kyseinen opettaja oli hyvä, ja Musa vahvistaa tämän tulkinnan. Olennaista Musan vastauksessa on se, että koulusta oppimisen paikkana puhuessaan hän heti täsmentää vastauksensa nimenomaan opettajaan liittyväksi. Koulu ei siis ole kokonaisuudessaan maininnan arvoinen oppimisen paikka vaan vastauksessa olennaista on vuorovaikutussuhde opettajan kanssa. Samaan tapaan kuin kavereissakin, institutionaalisessakin yhteydessä kielenkäytön ja oppimisen mahdollisuudet liitetään ensisijaisesti tiettyihin henkilöihin.

Opettajien merkityksellisyys nousee esiin myös muutamissa muissa haastatteluissa, joissa käy myös ilmi, että koulun kielellinen todellisuus ei välttämättä ole niin yksiselitteinen, millaisena haastattelija sen joissakin kysymyksissä esittää (ks. myös Lehtonen 2015). Tästä muistuttaa esimerkkikatkelma 11, jossa haastateltava Alina purkaa haastattelijan oletusta siitä, että koulun pääasiallinen kieli olisi suomi.

\section{Esimerkki 11. Suomea puhutaan opettajan kanssa}

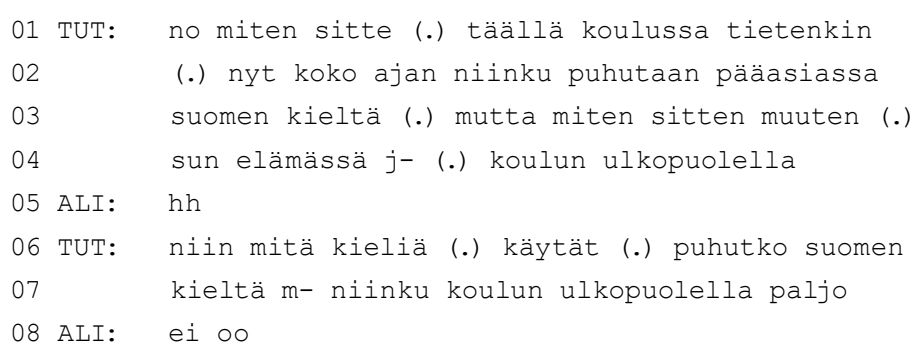




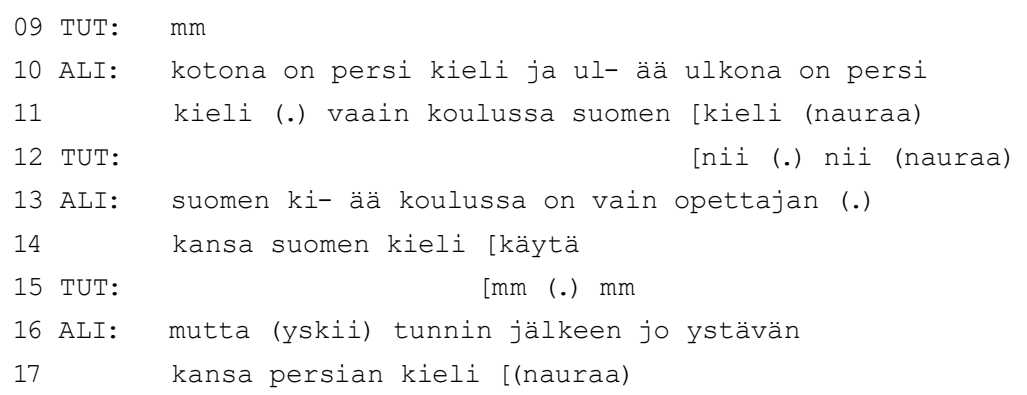

Tässä haastattelija kysymyksessään luonnehtii koulua paikaksi, jossa käytetään pääasiallisesti suomen kieltä ja kysyy Alinalta, mitä kieliä tämä käyttää koulun ulkopuolisessa elämässään. Alina toteaa käyttävänsä koulun ulkopuolella vain persiaa ja lisää sitten naurahtaen käyttävänsä suomea vain koulussa ja koulussakin vain opettajan kanssa (r. 10-14). Koulun kielenkäyttöympäristöt eivät siis ole yksiselitteisen suomenkieliset, vaikka haastattelija tällaista oletusta kysymyksessään rakentaakin. Pikemminkin koulussa suomen kieli liittyy ennen kaikkea vuorovaikutussuhteeseen opettajan kanssa ja välitunneilla kavereiden kanssa puhutaan muita kieliä.

Tässä alaluvussa käsitellyt esimerkit nostavat kaikki siis esiin viittauksia niin sanottujen "heikkojen vuorovaikutussuhteiden" merkityksellisyyteen. Erityisesti opettajat mutta myös sosiaalityöntekijät tai asiakaspalvelijat voivat olla tärkeitä vuorovaikutuskumppaneita suomen kielen käytön ja oppimisen näkökulmasta - erityisesti tilanteissa, joissa suomalaisia kavereita ei ole.

\section{LOPUKSI}

Olen tässä artikkelissa analysoinut maahanmuuttajanuorten haastattelupuheessa rakentuvia suomen kielen käyttöön ja oppimiseen liittyviä kategorioita. Olen analyysissa osoittanut, että nuorten puheessa erityisesti suomalaisen kaverin kategoria on merkityk- sellinen suomen kielen käytön ja oppimisen mahdollisuuksista puhuttaessa. Kaverin kategoria jäsentää erityisesti puhetta koulun ulkopuolisista kielenkäyttötilanteista. $\mathrm{Ne}$ haastateltavat, joilla on suomalaisia kavereita, erittelevät puheessaan analyyttisesti sitä, miten kielen oppiminen tapahtuu osana keskusteluja. He nostavat esiin esimerkiksi toiston ja kysymisen mahdollisuudet ja korostavat sitä, että vuorovaikutussuhde kaverin kanssa on turvallinen, mikä edesauttaa kysymistä.

Kaverin kategoria nousee haastattelupuheessa kuitenkin merkitykselliseksi myös poissaolon kautta. Kaikilla suomalaisia kavereita ei ole, ja monessa haastattelussa kavereiden puute yhdistetään suoraan vähäisiin mahdollisuuksiin käyttää suomen kieltä vapaa-ajalla. Havainnollistin analyysissani kuitenkin myös, että nekin haastateltavat, joilla suomalaisia kavereita ei ole, tunnistavat sen, että kielen käyttö vertaisten kanssa tarjoaisi mahdollisuuksia oppimiseen. Tämä näkyy esimerkiksi heidän hypoteettisista tarinoistaan siitä, että jos kavereita olisi, heidän kanssa puhuessa voisi oppia suomea.

Kavereista puhuttiin lähes jokaisessa haastattelussa. Muiden vuorovaikutussuhteiden merkityksellisyydestä kielen käytössä ja oppimisessa puhuttiin haastatteluvuorovaikutuksessa selvästi harvemmin. Niissä harvoissa tapauksissa, joissa nostettiin esiin muita tärkeitä ihmiskategorioita, puhuttiin opettajista, sosiaalityöntekijöistä ja asiakaspalvelun ammattilaisista esimerkiksi kaupoissa. Nimitin näitä 
suhteita "heikoiksi vuorovaikutussuhteiksi" Kokkosen (2010) tutkimuksen mukaan. Kokkonen on pakolaisten vuorovaikutussuhteita Suomessa käsittelevässä tutkimuksessaan todennut, että vaikka heikot vuorovaikutussuhteet eivät ole välttämättä kovin läheisiä, niillä voi kuitenkin olla iso merkitys ihmisille itselleen. Joissakin tilanteissa esimerkiksi kielten opettajat voivat olla lähes ainoa maahanmuuttajan kontakti kantaväestöön. Tässä artikkelissa analysoimani haastatteluaineisto tukee Kokkosen (2010) tekemiä havaintoja ja nostaa esiin sen, että erityisesti kielen käytön näkökulmasta myös nämä heikot vuorovaikutussuhteet ovat tärkeitä.

Kielen oppimista jäsentävistä paikkakategorioista analyysissani nousivat selvästi esiin koulu ja koulun vastakohdaksi asettuva sen ulkopuolinen kielenkäyttöympäristö, johon viitattiin haastatteluissa esimerkiksi puhumalla kadusta tai käyttämällä adverbia ulkona. Haastateltavat puhuivat paljon näiden eri kielenkäyttöympäristöjen kielimuotojen erilaisuudesta. Heidän puheessaan rakentui selvästi myös arvoasetelmia: koulun kieltä pidettiin ainakin joissakin haastatteluissa lähes tarpeettomana juuri siitä syystä, että sen käyttö rajoittuu koulun puhetilanteisiin. Koulun ulkopuolella tarvittaisiin toisenlaista rekisteriä, jotta olisi mahdollista osallistua vuorovaikutustilanteisiin tasavertaisena jäsenenä - ilman että tulisi tunnistetuksi suomen kielen oppijaksi tai "uudeksi suomalaiseksi".

Tavoitteenani tässä artikkelissa oli myös tuoda uusia näkökulmia käsitysten tutkimuksen menetelmiin ja sovelsin analyysissani aineistolähtöisen sisällönanalyysin lisäksi jäsenkategoria-analyysia. Mielestäni tämä menetelmällinen ratkaisu toimi tässä aineistossa hyvin, koska haastateltavien maahanmuuttajanuorten käsitykset kielen käytön ja oppimisen mahdollisuuksista tietyllä tavalla kilpistyvät aineistossa keskeisiin ihmis- ja paikkakategorioihin eli kavereihin, kouluun ja "katuun". Kategorioihin fokusoiminen nostaa tässä tapauksessa esille myös sellaiset keskeiset vastakkainasettelut, jotka selvästi jäsentävät maahanmuuttajanuorten kielellistä todellisuutta ja puhetta siitä. Erityisesti koulun ja koulua ympäröivän kielimaailman asettuminen näin selvästi vastakkain on asia, joka ei ole uusi, mutta johon on syytä kiinnittää huomiota.

Suomi toisena kielenä -opettajat ovat vuosikausia keskustelleet siitä, mikä kielimuoto olisi otettava opetuksen pohjaksi: tulisiko suomea toisena kielenä opiskeleville opettaa ensisijaisesti puhekielen muotoa vai tulisiko opetuksessa painottaa alusta lähtien yleiskielen muotojen hallintaa. Tähän keskusteluun toi painokkaan puheenvuoron väitöskirjallaan Lehtonen (2015), jonka analyysi toisaalta toi esille sellaisia rekisteriytymisen prosesseja, jotka osoittavat, että Suomessakin on jo ainakin joissakin konteksteissa tunnistettavissa ulkomaalaisten suomelle tyypillisiä kielellisiä piirteitä, joiden kehittymisen voi osaltaan jäljittää opetuspuheeseen eli siihen, miten suomi toisena kielenä -opettajat puhuvat ja millaisia kielimuotoja he opetuksessaan suosivat (ks. myös Storhammar, 1994). Tällainen kehityskulku ei välttämättä ole toivottava, jos se johtaa sellaisiin kokemuksiin, joista esimerkiksi Ahmed ja Ibrahim haastattelupuheessaan raportoivat (ks. esimerkit 7 ja 8). $\mathrm{He}$ puhuivat siitä tunnistamastaan kokemuksesta, että jos he käyttävät koulussa opetettua yleiskielistä rekisteriä luokkahuoneen ulkopuolella, heidät tunnistetaan maahanmuuttajiksi. Vaikka kysymykseen siitä, millaista kielimuotoa suomi toisena kielenä -opetuksessa tai muussa suomea toisena kielenä käyttäville oppilaille suunnatussa opetuksessa tulisi ensisijaisesti suosia, ei varmasti ole yksiselitteistä vastausta, antaa tässä tehty analyysi yhdessä monien muiden aiemmin mainittujen tutkimusten kanssa kuitenkin selvän viestin siitä, että koulumaailman ja koulumaailmaa ym- 
päröivän kielenkäyttöyhteisön kielimuotojen erilaisuus tulisi ottaa opetuksessa huomioon ja eksplisiittisesti esille aivan alusta lähtien. Suomi toisena kielenä opetuksessa on myös selvä tarve sitoa luokkahuoneen ulkopuoliset kieliympäristöt tiiviimmin osaksi luokkahuoneiden kielenopetusta ja auttaa oppijoita paitsi tunnistamaan eri rekistereiden piirteitä myös käyttämään niitä (ks. Lilja \& PiirainenMarsh 2018). Kielenopetuksen tulisi tarjota oppijoille mahdollisuuksia osallistua niihin kielenkäyttötilanteisiin, jotka heidän elämänpiirissään ovat merkityksellisiä. Tässä analysoidut esimerkit osoittavat, että oppijat ovat hyvinkin tietoisia siitä, miten puhutuissa vuorovaikutustilanteissa opitaan. Tämä tieto olisi hyvä valjastaa myös pedagogiseen käyttöön. Onkin ehkä ennen kaikkea pedagoginen kysymys, miten vastakkainasettelua koulun ja "kadun" kielimaailman välillä nuorten kokemusmaailmassa saataisiin kavennettua.

Poliittisessa ja pedagogisessa keskustelussa on toki aivan perustellusti kannettu huolta ennen kaikkea institutionaalisesta kielikoulutuksesta ja esimerkiksi aikuisten maahanmuuttajien kieliopinnoista ja sujuvasta siirtymisestä työmarkkinoille (ks. esim. Pyykkö, 2017; Valtion kotouttamisohjelma vuosille 2012-2015, 2016-2019). Meillä alkaa kuitenkin olla jo tarpeeksi tutkimusta erilaisissa elämäntilanteissa Suomessa elävistä maahanmuuttajataustaisista henkilöistä, jotka ovat haastattelututkimuksissa raportoineet vaikeuksistaan päästä osaksi esimerkiksi työpaikkojen sosiaalisia yhteisöjä kielimuurin takia tai kuten tässä esitetyssä aineistossa, kertoneet kavereiden puutteesta tai siitä, että koulun kielen käyttäminen saa heidät kuulostamaan kielen oppijalta, mikä ei kaikissa yhteyksissä ole toivottava identiteettikategoria (ks. esim. Härkönen, 2011; Kokkonen, 2010; Kulju, 2016; Laakso, 2015; Palmanto, 2004; Partanen, 2012; Tarnanen ym., 2015; Virtanen, 2017). Nämä kaikki tutkimukset yhdessä an- taisivat aihetta nostaa niin pedagogiseen kuin poliittiseenkin keskusteluun pohdinnan siitä, miten voisimme sujuvoittaa suomea toisena kielenä käyttävien henkilöiden pääsyä osaksi suomenkielisiä kielenkäyttöyhteisöjä myös arkisen elämän vaihtelevissa sosiaalisissa tilanteissa. Tällaisella keskustelulla voisi olla tärkeä yhteiskunnallinen merkitys, koska eri etnisten, kielellisten tai sosiaalisten ryhmien erkaantumisella toisistaan yhteiskunnassamme tuskin on positiivisia seurauksia. Tässä analysoitu aineisto antaa syytä pohtia erityisesti sitä, että kotoutumisessa on kyse muustakin kuin oikean opiskelupaikan löytämisestä ja työelämään pääsystä, vaikka nämä toki keskeisïa tavoitteita ovatkin. Kotoutuminen tarkoittaa myös merkityksellisten sosiaalisten vuorovaikutusympäristöjen löytämistä ja niihin kiinnittymistä ja myös tätä tulisi tukea mahdollisuuksien mukaan.

Suomalaisten peruskoulujen vuodesta 2014 lähtien käyttöön otetuissa opetussuunnitelmien perusteissa puhutaan kielitietoisuudesta sekä siitä, miten jokainen opettaja on kielen opettaja (ks. OPH, 2014). Tällaisen ymmärryksen toivoisi leviävän koulujen lisäksi laajemmallekin yhteiskuntaan (ks. myös Lilja, Latomaa \& Luukka, 2017). Tässä analysoitu aineisto osoittaa, että maahanmuuttajan kokemusmaailmassa myös sosiaalityöntekijä tai kaupan kanssa voi olla tärkeä suomenkielinen kontakti ja tietyssä tilanteessa myös suomen kielen opettaja. Molemminpuolisen kotoutumisen näkökulmasta olisi tärkeää nostaa esiin tätä heikkojen vuorovaikutussuhteiden merkityksellisyyttä ja ajatusta siitä, että on tärkeää tarjota suomea opetteleville kielenkäyttäjille suomen kielen käytön ja oppimisen mahdollisuuksia. Tämä tehtävä ei kuulu vain kielten opettajille vaan ihan meille kaikille. 


\section{LÄHTEET}

Alanen, R. (2003). A sociocultural approach to young language learners' beliefs about language learning. Teoksessa P. Kalaja \& A. M. F. Barcelos (toim.), Beliefs about SLA: New research approaches (s. 55-85). Dordrecht: Kluwer Academic Publishers.

Alanen, R., Kalaja, P. \& Dufva, H. (2013). Visuaaliset narratiivit ja valmistuvien aineenopettajien käsitykset vieraiden kielten opettamisesta. AFinLA-e: Soveltavan kielitieteen tutkimuksia, 5, 41-56.

Alasuutari, P. (1995). Researching culture: Qualitative method and cultural studies. London: Sage.

Aro, M. (2009). Speakers and doers. Polyphony and agency in children's beliefs about language learning. Väitöskirja. Jyväskylän yliopiston kielten laitos. Jyväskylä Studies in Humanities 116.

Aro, M. (2016). Authority versus experience: Dialogues on learner beliefs. Teoksessa P. Kalaja, A. M. F. Barcelos, M. Aro \& M. Ruohotie-Lyhty (toim.), Beliefs, agency and identity in foreign language learning and teaching (s. 27-46). Basingstoke: Palgrave Macmillan.

Baker, C. (1997). Membership categorization and interview accounts. Teoksessa D. Silverman (toim.), Qualitative research: Theory, method and practice (s. 130-143). London: Sage.

Baker, C. (2002). Ethnomethodological analyses of interviews. Teoksessa J. Gubrium, \& A. Holstein (toim.), Handbook of interview research (s. 777-795). Thousand Oaks: Sage.

Barcelos, A. M. F. (2003). Researching beliefs about SLA: A critical review. Teoksessa P. Kalaja \& A. M. F. Barcelos (toim.), Beliefs about SLA: New research approaches (s. 7-33). Dordrecht: Kluwer Academic Publishers.

Cummins, J. (1984). Bilingualism and special education: Issues in assessment and pedagogy. Clevedon: Multilingual Matters.

Douglas Fir Group. (2016). A transdisciplinary framework for SLA in a multilingual world. The Modern Language Journal, 100 (Supplement), 19-47.

Dufva, H. (13.3.2014). Vieraasta kielestä omiksi sanoiksi: Mitä Vološinov sanoi kielen oppimisesta ja opettamisesta? Kieliverkoston verkkolehti. Haettu osoitteesta: https://www. kieliverkosto.fi/fi/article/vieraasta-kielesta- omiksi-sanoiksi-mita-volosinov-sanoi-kielenoppimisesta-ja-opettamisesta

Georgakopoulou, A. (2007). Small stories, interaction and identities. Amsterdam: John Benjamins.

Heimala-Kääriäinen, E. (2015). Seurassa parempaa sairaalasuomea: Ammatillisen kielitaidon oppiminen ja kollegojen kielellinen tuki sairaalaympäristössä. Pro gradu tutkielma. Jyväskylän yliopisto, humanistinen tiedekunta, suomen kieli.

Hester, S. \& Eglin, P. (toim.). (1997). Culture in action: Studies in membership categorization analysis. Washington DC: International Institute for Ethnomethodology and Conversation Analysis / University Press of America.

Huttunen, M. (14.3.2013). Maahanmuuttajanuorille räätälöityä luku- ja kirjoitustaidon koulutusta Tampereella. Kieli, koulutusjayhteiskunta, 4(1).

Härkönen, A. (2011). Suomen kielen sosiaalinen oppiminen työyhteisössä: IT-alan työperusteiset maahanmuuttajat suomalaisessa työyhteisössä. Pro gradu -tutkielma. Jyväskylän yliopisto, humanistinen tiedekunta, suomen kieli.

Jokinen, A., Juhila, K. \& Suoninen E. (toim.). (2012). Kategoriat, kulttuuri \& moraali. Johdatus kategoria-analyysiin. Tampere: Vastapaino.

Kalaja, P., Barcelos, A. M. F. \& Aro, M. (2018). Revisiting research on learner beliefs: Looking back and looking forward. Teoksessa P. Garrett \& J. M. Cots (toim.), The Routledge Handbook of Language Awareness (s. 222-237). New York: Routledge.

Kokkonen, L. (2010). Pakolaisten vuorovaikutussubteet. Keski-Suomeen muuttaneiden pakolaisten kokemuksia vuorovaikutussubteistaan ja kiinnittymisestään uuteen sosiaaliseen ympäristöön. Väitöskirja. Jyväskylän yliopiston kielten laitos. Jyväskylä Studies in Humanities 143.

Kokkonen, M. (2007). Vaatimuksena sujuva suomi. Virittäjä, 111, 253-261.

Kulju, J. (2016). Yksilön ja yhteisön kielitaitoa - maahanmuuttajaopiskelijoiden kertomuksia kommunikointihalukkuudestaan ja käsityksistään suomesta opiskelukielenä ammatillisessa koulutuksessa. Teoksessa A. Solin, J. Vaattovaara, N. Hynninen \& T. Nordlund (toim.), Kielenkäyttäjä munttuvissa instituutioissa. The language user in changing institutions. AFinLAn 
vuosikirja 2016. Suomen soveltavan kielitieteen yhdistyksen julkaisuja 74 (s. 127-144). Jyväskylä: Suomen soveltavan kielitieteen yhdistys.

Laakso, S. (2015). Alkuvaiheen S2-oppijoiden käsityksiä puheen ymmärtämisen vaikeuksista ja kompensaatiostrategioista. Teoksessa $\mathrm{T}$. Jakonen, J. Jalkanen, T. Paakkinen \& M. Suni (toim.), Kielen oppimisen virtauksia. Flows of language learning. AFinLAn vuosikirja 2015. Suomen soveltavan kielitieteen yhdistyksen julkaisuja 73 (s. 91-112).

Lehtonen, H. (2015). Tyylitellen. Nuorten kielelliset resurssit ja kielen sosiaalinen indeksisyys monietnisessä Helsingissä. Väitöskirja. Helsinki: Helsingin yliopisto.

Lilja, N. (2010). Ongelmista oppimiseen. Toisen aloittamat korjausjaksot kakkoskielisessä keskustelussa. Väitöskirja. Jyväskylän yliopisto. Jyväskylä Studies in Humanities 146.

Lilja, N., Luukka, E. \& Latomaa S. (2017). Kielitietoisuus eriarvoistumiskehitystä jarruttamassa. Teoksessa S. Latomaa, E. Luukka \& N. Lilja (toim.), Kielitietoisuus eriarvoistuvassa yhteiskunnassa - Language awareness in an increasingly unequal society. AFinLAn vuosikirja 2017. Suomen soveltavan kielitieteen yhdistyksen julkaisuja 75 (s. 11-29).

Lilja, N. \& Piirainen-Marsh, A. (2018). Connecting the language classroom and the wild: Reenactments of language use experiences. Applied Linguistics, 2018, 1-31.

Mähönen, E. (2014). Maahanmuuttajalääkärin kokemuksia ammatillisen kielitaidon kehittymisestä: "no se mun kurssi oli töissä. Pro gradu -tutkielma. Jyväskylän yliopisto, humanistinen tiedekunta, suomen kieli.

Nikander, P. (2010). Jäsenkategoria-analyysi ja haastattelun kulttuuriset järjestykset. Teoksessa J. Ruusuvuori, P. Nikander \& M. Hyvärinen (toim.), Haastattelun analyysi (s. 242-268). Tampere: Vastapaino.

Nikander, P. (2012). Interviews as discourse data. Teoksessa J. F. Gubrium, J. A. Holstein, A. B. Marvasti \& K. D. McKinney (toim.), The SAGE handbook of interview research. The complexity of the craft (2. painos) (s. 397-413). London: Sage.

Nikula, T. \& Pitkänen-Huhta, A. (2008). Using photographs to access stories of learning English. Teoksessa P. Kalaja, V. Menezes \& A. Barcelos (toim.), Narratives oflearning and teaching
EFL (s.171-185). Houndmills, Basingstoke: Palgrave.

OPH (2014). Perusopetuksen opetussuunnitelman perusteet 2014. Helsinki: Opetushallitus.

Palmanto, M. (2004). Suomenoppijoiden kokemuksia kielenkäytön ja kielitaidon kehittymisestä työharjoittelussa. Virittäjä, 3, 405-414.

Partanen, M. (2012). Matkalla sairaalaan: maahanmuuttajien käsityksiä suomen kielen oppimisesta sisä̈̈ntuloammatissa. Pro gradu -tutkielma. Jyväskylän yliopisto, humanistinen tiedekunta, suomen kieli.

Partanen, M. (2013a). Kieli tulee kielen päälle: kansainvälisten opiskelijoiden käsityksiä suomen kielen oppimisesta. Teoksessa M. Eronen \& M. Rodi-Risberg (toim.), Haasteena näkökulma, Perspektivet som utmaning, Point of view as challenge, Pespektivität als Herausforderung. VAKKI-symposiumi XXXIII 7.-8.2.2013 (s.257-268). VAKKI publications 2. Vaasa: VAKKI.

Partanen, M. (2013b). Suomen kielen oppimisen mahdollisuudet ja työyhteisön tuki puhdistuspalvelualalla: Afrikkalaisten maahanmuuttajien käsityksiä ja kokemuksia. Teoksessa T. Keisanen, E. Kärkkäinen, M. Rauniomaa, P. Siitonen \& M. Siromaa (toim.), Osallistumisen multimodaaliset diskurssit. AFinLAn vuosikirja 2013. Suomen soveltavan kielitieteen yhdistyksen julkaisuja 71 (s. 55-76).

Pyykkö, R. (2017). Monikielisyys vahvuudeksi. Selvitys Suomen kielivarannon tilasta ja tasosta. Opetus- ja kulttuuriministeriön julkaisuja 2017:51.

Sacks, H. (1992). Lectures on conversation (vol. I \& II). Oxford: Blackwell.

Sandwall, K. (2013). Att hantera praktiken - om sfi-studerandes möjligheter till praktikplatser. Väitöskirja. Göteborgin yliopisto.

Savijärvi, M. (2011). Yhteisestä toiminnasta yhteiseen kieleen. Keskustelunanalyyttinen tutkimus toisen kielen oppimisesta kielikylpypäiväkodin arkitilanteissa. Väitöskirja. Helsinki: Helsingin yliopisto.

Schegloff, E. (2007a). Tutorial on membership categorization. Journal of Pragmatics, 39, 462482.

Schegloff, E. (2007b). Categories in action: Person-reference and membership categorization. Discourse Studies, 9, 433-461. 
Speer, S. (2002). "Natural" and "contrieved" data: A sustainable distinction? Discourse Studies, 4, 511-525.

Storhammar, M-T. (1994). Puhekielen asema ulkomaalaisopetuksessa. Virittäjä, 1, 97-109.

Strömmer, M. (2017). Mahdollisuuksien rajoissa. Neksusanalyysi suomen kielen oppimisesta siivoustyössä. Väitöskirja. Jyväskylä: Jyväskylän yliopisto.

Suni, M. (2008). Toista kieltä vuorovaikutuksessa. Kielellisten resurssien jakaminen toisen kielen omaksumisen alkuvaiheessa. Väitöskirja. Jyväskylän yliopisto. Jyväskylä Studies in $\mathrm{Hu}$ manities 94.

Suni, M. (2010). Työssä opittua: Työntekijän näkökulma ammatilliseen kieli- ja viestintätaitoonsa. Teoksessa M. Garant \& M. Kinnunen (toim.), Ammatillinen viestintä, koulutus ja kulttuuri (s. 45-58). AFinLA-e: Soveltavan kielitieteen tutkimuksia 2.

Svennevig, J. (2017). "What's it called in Norwegian?" Acquiring L2 vocabulary items in the workplace. Journal of Pragmatics, 126, 68-77.

Tarnanen, M., Rynkänen T. \& Pöyhönen, S. (2015). Kielten käyttö ja oppiminen aikuisten maahanmuuttajien integroitumisen ja identiteettien rakennusaineina. Teoksessa T. Jakonen, J. Jalkanen, T. Paakkinen \& M. Suni (toim.),
Kielen oppimisen virtauksia. Flows of language learning (s. 56-72). AFinLAn vuosikirja 2015. Suomen soveltavan kielitieteen yhdistyksen julkaisuja 73.

Tourunen, A. (2016). Jelmu-suomea: suomen kielen käyttö ja oppiminen vapaaehtoistyössä. Pro gradu -tutkielma. Jyväskylän yliopisto, humanistinen tiedekunta, suomen kieli.

Tuomi, J. \& Sarajärvi A. (2002). Laadullinen tutkimus ja sisällönanalyysi. Helsinki: Tammi.

Valtion kotouttamisohjelma vuosille 2012-2015.

Valtion kotouttamisohjelma vuosille 20162019, saatavilla: http://tem.fi/documents/1410877/3506436/Valtion+kotoutta misohjelma+vuosille+2016-2019.pdf

van Lier, L. (2000). From input to affordance: Social interactive learning from an ecological perspective. Teoksessa J. P. Lantolf (toim.), Sociocultural theory and second language learning: Recent advances (s. 245-259). Oxford: Oxford University Press.

Virtanen, A. (2017). Toimijuutta toisella kielellä: Kansainvälisten sairaanhoitajaopiskelijoiden ammatillinen suomen kielen taito ja sen kehittyminen työharjoitteluissa. Väitöskirja. Jyväskylän yliopisto. Jyväskylä Studies in Humanities 311. 


\section{LIITE 1}

Haastatteluaineistojen litteroinnissa on käytetty seuraavia merkkejä:

(.) alle sekunnin mittainen tauko

(1.4) sekuntia pidempi tauko

$=\quad$ kaksi puhunnosta liittyy toisiinsa tauotta

[ päällekkäispuhunnan alku

: $\quad$ äänteen venytys

( - ) sana, josta ei ole saatu selvää

( - - ) pidempi jakso, josta ei ole saatu selvää

((kaksoissulkeiden sisällä litteroijan kommentteja ja selityksiä tilanteesta)) 


\section{"I LEARN ON THE STREETS WITH FRIENDS" YOUNG ADULT IMMIGRANTS CATEGORIZING THE OPPORTUNITIES FOR USING AND LEARNING FINNISH AS L2}

Niina Lilja, University of Tampere

This paper analyses the beliefs that young adult immigrants have about the Finnish language, the learning process and the places of using and learning Finnish. The analysis is based on interview data and the data is analyzed by combing the methods of content analysis and membership categorization analysis.

The analysis shows that in the interviews, the category of a friend becomes important, and especially Finnish friends are regarded central in facilitating the language learning process. The absence of Finnish friends is connected to the lack of possibilities to use Finnish in everyday situations. The place categories of the school and outside of school are also frequently oriented to as important in the interview talk. The language practices in school are regarded as very different from the language practices outside of school by the interviewees. The analysis show how this contrast is constructed and how it also reflects language ideologies and beliefs about what kind of language is needed to be able to integrate into the social groups the young interviewees regard as meaningful and relevant for their everyday life.

Keywords: beliefs, Finnish as a second language, immigrants, membership categorization analysis, second language learning 